\title{
OPIEKA PIELEGGNIARSKA NAD PACJENTEM PO PRZEBYTYM ZAWALE SERCA I ANGIOPLASTYCE WIEŃCOWEJ - STUDIUM PRZYPADKU
}

\section{NURSING CARE OF THE PATIENT AFTER MYOCARDIAL INFARCTION AND CORONARY ANGIOPLASTY - CASE STUDY}

\author{
Kinga Duszak ${ }^{1, a}$, Anna Zera ${ }^{2, b}$, Andrzej Krupienicz ${ }^{2, c}$ \\ ${ }^{1}$ Studentka pielęgniarstwa II stopnia, Warszawski Uniwersytet Medyczny \\ ${ }^{2}$ Zakład Podstaw Pielęgniarstwa, Warszawski Uniwersytet Medyczny \\ ${ }^{a}$ https://orcid.org/0000-0001-9885-4677 \\ ${ }^{\mathrm{b}} \mathrm{https}: / /$ orcid.org/0000-0002-7536-4357 \\ ${ }^{c}$ https://orcid.org/0000-0003-4466-3650
}

DOI: https://doi.org/10.20883/pielpol.2021.5

\section{STRESZCZENIE}

Założenia. Ostry zespół wieńcowy jest najbardziej rozpowszechnioną postacią choroby niedokrwiennej serca. Leczenie pacjenta opiera się głównie na udrożnieniu tętnicy dozawałowej za pomocą farmakoterapii bądź poprzez zastosowanie przezskórnych metod rewaskularyzacyjnych i wiąże się z występowaniem wielu powikłań. Z tego względu okres hospitalizacji po zabiegu łączy się z wieloma problemami pielęgnacyjnymi.

Prezentacja przypadku. Celem pracy było przedstawienie problemów pacjenta po zawale mięśnia sercowego oraz zabiegu angioplastyki wieńcowej i zaplanowanie dla niego opieki pielęgniarskiej.

Wyniki. W bezpośredniej opiece nad pacjentem po zabiegu angioplastyki wieńcowej brał udział personel pielęgniarski. Zmniejszono ryzyko wystąpienia groźnych powikłań. W wyniku wnikliwej obserwacji i analizy parametrów chorego (tętna, ciśnienia tętniczego krwi, saturacji, oddechów) oraz skutecznej farmakoterapii hospitalizacja pacjenta przebiegła w sposób prawidłowy. Przeprowadzono edukację pacjenta na temat zdrowego trybu życia oraz szybkiego powrotu do samodzielnego funkcjonowania.

SŁOWA KLUCZOWE: zawał serca, angioplastyka wieńcowa, opieka pielęgniarska.

\section{Wprowadzenie}

Z powodu chorób sercowo-naczyniowych w 2016 roku zmarło 17,9 mln ludzi, co stanowi około 31\% zgonów na całym świecie. Z kolei $85 \%$ z tych zgonów było spowodowane zawałem serca i udarem mózgu [1]. Choroby układu sercowo-naczyniowego stanowią również w Polsce jeden z głównych problemów zdrowotnych. Pomimo poprawy sytuacji epidemiologicznej i rozwoju kardiologii inwazyjnej, współczynniki umieralności

\begin{abstract}
Assumptions. The acute coronary syndrome is the most common form of ischemic heart disease. Patient's treatment is mainly based on unblocking the infarct-related artery through pharmacotherapy or transcutaneous revascularization methods, and it is associated with many complications. The hospitalization period after the confluence connects to many nursing problems.

Presentation of the case. The aim of the study was to present the patient's problems after myocardial infarction as well as coronary angioplasty, and to plan nursing care for this patient.

Results. The patient's condition after coronary angioplasty surgery depended mainly on nursing staff. The risk of serious complications has been reduced. As a result of careful observation and analysis of the patient's parameters and also effective pharmacotherapy, the patient's hospitalization was carried out correctly. The patient was educated about a healthy lifestyle and a quick recovery.
\end{abstract}

KEYWORDS: myocardial infarction, coronary angioplasty, nursing care.

przedwczesnej są w dalszym ciągu zbyt wysokie [2] Zawał serca jest jedną z najbardziej znanych postaci choroby wieńcowej [3]. Na rozwój chorób układu krążenia wpływa wiele czynników ryzyka. Dzieli się je na modyfikowalne (palenie papierosów, nadciśnienie tętnicze, cukrzyca, brak ruchu, stres) oraz niemodyfikowalne (wiek, płeć męska, dodatni wywiad rodzinny) [2]. Przyczyną powstania myocardial infarction MI, zawału serca jest najczęściej niedokrwienie w skutek nagłego 
zamknięcia lub zwężenia jednej z tętnic wieńcowych. Spowodowane jest to skrzepliną, skurczem naczynia lub narastającą nadżerką miażdżycową. Trwający dłużej niż 15-30 minut brak dopływu krwi do określonego obszaru mięśnia sercowego powoduje natychmiastową utratę czynności kurczliwej, co może przejawiać się różnymi objawami klinicznymi: ból w okolicy zamostkowej, promieniujący do ramion, szyi, nadbrzusza, żuchwy, duszność, osłabienie, zawroty głowy, kołatanie serca, nudności, poty, bladość powłok, przyśpieszenie rytmu serca [4-6]. We krwi pojawiają się swoiste biomarkery, które mogą wskazywać na trwający zawał serca. Stężenie troponiny sercowej (l lub T) wzrasta po 3-12 godzinach po zamknięciu tętnicy wieńcowej. Alternatywą jest oznaczenie stężenia CK-MB (kinaza keratynowa), którego wartość wzrasta po około 4 h od wystąpienia zawału [6]. Głównym celem leczenia STEMI (zawał serca z uniesieniem odcinka ST) jest przywrócenie perfuzji mięśnia sercowego i przepływu krwi przez tętnicę odpowiedzialną za zawał [7]. Możliwe jest to dzięki zastosowaniu leczenia trombolitycznego i przezskórnych interwencji wieńcowych [8]. Wstępne leczenie ogranicza się do tlenoterapii pacjenta w sytuacji gdy Sp02 wynosi mniej niż $90 \%$ oraz stabilizacji bólu. Podawany jest także kwas acetylosalicylowy, azotany oraz opioidy. Aspiryna zmniejsza śmiertelność u pacjentów z OZW (ostry zespół wieńcowy), dlatego powinna być podawana jak najwcześniej i kontynuowana jak najdłużej. Zalecana dawka nasycająca aspiryny wynosi 162-325 mg. Stosowanie azotanów powoduje rozluźnienie mięśni gładkich naczyń, co wpływa na zwiększenie perfuzji niedokrwionej strefy mięśnia sercowego. Morfina jest zalecana jako środek wspomagający łagodzenie bólu. Jest podawana dożylnie w początkowej dawce 2-4 mg, następnie dodatkowe bolusy 2-8 mg dożylnie co 5-15 minut. Pierwotna PCI (przezskórna interwencja wieńcowa) jest terapią z wyboru dla STEMI, jeśli może być przeprowadzona w odpowiednim czasie przez wykwalifikowanego operatora. Normalna perfuzja w zawale mięśnia sercowego jest przywracana u około 95\% pacjentów leczonych pierwotną $\mathrm{PCl}$, w porównaniu do $54 \%$ pacjentów leczonych trombolizą. Pomaga to wyjaśnić stałą wyższość pierwotnej przezskórnej angioplastyki wieńcowej (PTCA) nad trombolizą [7]. Lepsze efekty, które zapobiegają restenozie, uzyskuje się poprzez zastosowanie podczas PTCA stentu naczyniowego. Stent umieszczany jest w tętnicy w miejscu zwężenia przy pomocy balonu. Pozostaje w niej na całe życie i zapobiega nawrotom zwężenia w tym miejscu [9]. Mechanizm działania leków trombolitycznych opiera się na rozpuszczeniu włóknika zawartego w zakrzepie i udrożnieniu tętnicy dozawałowej. Wykorzystuje się leki, takie jak streptokinaza, alteplaza, reteplaza, tenekteplaza. U pacjentów ze STEMI i chorobą wielonaczyniową, u których wykonano PCI tętnicy odpowiedzialnej za zawał (pierwotną lub po leczeniu trombolitycznym), a także potwierdzono występowanie niedokrwienia w obszarach, które nie zostały objęte zawałem, dalsza rewaskularyzacja może zostać przeprowadzona przed wypisem ze szpitala lub w ciągu dni do tygodni po początkowej PCI [10]. Okres hospitalizacji wiąże się zazwyczaj z wystąpieniem licznych problemów pielęgnacyjnych. Nadzór nad pacjentem jest niezbędny zarówno przed jak i po zabiegu, głównie w zakresie: stabilizacji bólu, wykonaniu opatrunków uciskowych, zapewnieniu poczucia bezpieczeństwa, monitorowaniu parametrów życiowych chorego (tętno, ciśnienie tętnicze krwi, saturacja). Opieka pielęgniarska ukierunkowana jest na szybkie wykrywanie niepokojących objawów, a także wczesne rozpoznanie powikłań, które mogą wystąpić po zabiegu, takich jak: rozwarstwienie błony wewnętrznej, tamponada serca, wstrząs kardiogenny, nagłe zatrzymanie krążenia, zaburzenia rytmu serca [11]. Równie ważne jest wsparcie psychiczne i edukacja pacjenta.

Celem pracy było przedstawienie planu opieki pielęgniarskiej nad pacjentem po przebytym zawale serca i angioplastyce wieńcowej.

\section{Opis przypadku}

65-letni mężczyzna został przyjęty na Oddział Intensywnej Opieki Kardiologicznej w trybie nagłym z powodu silnego bólu w klatce piersiowej, promieniującego do lewej kończyny górnej, utrzymującego się około 2 godzin. Dodatkowo zgłaszał uczucie słabości i nudności. Dolegliwości pojawiły się w trakcie wysiłku fizycznego i utrzymywały się. W wywiadzie stwierdzono obecność następujących czynników ryzyka choroby niedokrwiennej serca: otyłość, palenie papierosów od około 25 roku życia (40 paczkolat, 20 szt./dobę), nadciśnienie tętnicze, wywiad rodzinny dodatni. W EKG stwierdzono obraz ostrego zespołu wieńcowego z przetrwałym uniesieniem ST. Chory miał wykonaną koronarografię, która wykazała zamknięcie prawej tętnicy wieńcowej. Wykonano udrożnienie PTW (prawa tętnica wieńcowa) i kolejno jej poszerzenie z implantacją stentu naczyniowego. Pacjenta przekazano na Oddział Intensywnej Opieki Kardiologicznej w celu dalszej obserwacji. U pacjenta zastosowano opatrunek uciskowy w prawej pachwinie. Posiadał wkłucie obwodowe w żyle grzbietu prawej dłoni. Ze względu na zastosowany opatrunek uciskowy w miejscu dostępu naczyniowego oraz reżim łóżkowy chory pozostawał w łóżku. Niechętnie podejmował próby zmieniania pozycji ułożeniowych z powodu bólu. Pacjent ze względu na występowanie wielu czynników ryzyka choroby niedokrwiennej serca został poinformo- 
wany o zagrożeniach płynących z aktualnego trybu życia w późniejszych etapach hospitalizacji.

Poniżej przedstawione zostały główne problemy pielęgnacyjne, jakie występowały w trakcie opieki nad pacjentem:

\section{Możliwość wystąpienia krwawienia z tętnicy ob- wodowej poddanej nakłuciu}

Cel opieki pielęgniarskiej: niedopuszczenie do nasilenia krwawienia.

Zastosowane interwencje pielęgniarskie: poinformowanie pacjenta o konieczności pozostania w pozycji leżącej z wyprostowaną kończyną dolną oraz o możliwości wystąpienia niepożądanych skutków nagłego poruszania kończyną, poinformowanie pacjenta o konieczności stosowania uciskającego opatrunku przez $24 \mathrm{~h}$, przekazanie informacji pacjentowi, że zastosowany opatrunek będzie usuwał personel medyczny i pacjent nie może sam decydować o jego ściągnięciu, ocena miejsca wkłucia pod kątem krwawienia lub krwiaka, monitorowanie parametrów życiowych (tętno, ciśnienie tętnicze krwi, oddechy).

Ocena działań: brak krwawienia

\section{Silny ból w klatce piersiowej z powodu niedokrwienia mięśnia sercowego}

Cel opieki pielęgniarskiej: zminimalizowane dolegliwości bólowych.

Zastosowane interwencje pielęgniarskie: zapewnienie dostępu do żyły w celu podania dożylnych leków przeciwbólowych (Paracetamol 1 g i.v.), podłączenie aparatury monitorującej parametry życiowe, obserwacja i zapis parametrów życiowych co 4 godziny: tętna, ciśnienia tętniczego krwi, saturacji, zapewnienie pacjentowi wygodnej pozycji, podanie na zlecenie lekarza tlenu (2-4 I/min przez maskę), zapewnienie ciszy i spokoju, obserwowanie umiejscowienia, charakteru i natężenia bólu, uczestniczenie w postępowaniu farmakologicznym: podano leki przeciwbólowe (morfina 2-4 mg s.c.) zgodnie ze zleceniem lekarskim, wykonano EKG na zlecenie lekarza, obserwowanie reakcji pacjenta na podane leki (brak reakcji alergicznej, ustąpienie dolegliwości bólowych), ocena skuteczności leczenia przeciwbólowego (użycie skali VAS).

Ocena działań: zmniejszenie dolegliwości bólowych występujących u pacjenta.

\section{Trudności w oddychaniu z powodu bólu w klatce piersiowej}

Cel opieki pielęgniarskiej: zmniejszenie duszności, ułatwienie oddychania.

Zastosowane interwencje pielęgniarskie: pomoc pacjentowi w zajęciu pozycji wysokiej, ocena zabarwienia skóry, monitorowanie i dokumentowanie parametrów życiowych co 4 godziny: tętna, ciśnienia tętniczego krwi, saturacji, kontrolowanie i ocena liczby oddechów, zapewnienie prawidłowej wilgotności powietrza w sali poprzez wietrzenie, zapewnienie ciszy i spokoju, zastosowanie tlenu na zlecenie lekarza (2-4 l/min przez maskę), dokumentowanie informacji o stanie chorego, podanie leków przeciwbólowych na zlecenie lekarza (morfina 2-4 mg s.c.).

Ocena działań: ułatwienie oddychania, zmniejszenie duszności.

\section{Lęk i niepokój spowodowany chorobą i poczuciem zagrożenia życia}

Cel opieki pielęgniarskiej: zmniejszenie niepokoju, zapewnienie poczucia bezpieczeństwa.

Zastosowane interwencje pielęgniarskie: zapewnienie ciszy i spokoju, stworzenie atmosfery bezpieczeństwa, umożliwienie rozmowy z lekarzem opiekującym się chorym podczas zwiększenia się niepokoju, wyjaśnienie choremu zasady i celowości wykonywanych czynności (pobierania krwi, podawania leków, kontroli parametrów), nawiązywanie kontaktu z chorym, zachęcanie do opisu przeżyć, podawanie leków uspokajających na zlecenie lekarza.

Ocena działań: zmniejszenie lęku i niepokoju u pacjenta.

\section{Niepokój pacjenta spowodowany niemiarowością akcji serca - tachykardia (145 uderzeń/minutę)}

Cel opieki pielęgniarskiej: umiarowienie akcji serca.

Zastosowane interwencje pielęgniarskie: ocena parametrów życiowych chorego (tętno, ciśnienie tętnicze, zabarwienie i wilgotność skóry), monitorowanie stanu i samopoczucia pacjenta, udzielanie informacji pacjentowi o wykonywanych czynnościach, podaż leków zgodnie z zaleceniem lekarza (metoprolol 2 x $50 \mathrm{mg} /$ dobę, p.o.), monitorowanie EKG, wykonanie EKG na zlecenie lekarza, podanie na zlecenia lekarza $5 \mathrm{mg}$ Betaloc i.v., obserwacja skóry pacjenta czy nie jest spocona i zimna.

Ocena działań: zmniejszenie niepokoju w wyniku umiarowienia akcji serca.

\section{Złe samopoczucie pacjenta z powodu podwyższonych wartości ciśnienia tętniczego (185/98 mmHg)}

Cel opieki pielęgniarskiej: utrzymanie wartości ciśnienia tętniczego w normie.

Zastosowane interwencje pielęgniarskie: monitorowanie wartości tętna, ciśnienia tętniczego krwi, obserwowanie zabarwienia powłok skórnych, podawanie leków zgodnie z zaleceniem lekarza (Captopril 25 mg/ dobę, Iporel mg 3x1 tabletka/dobę) spokojna rozmowa z pacjentem, poinformowanie pacjenta o konieczności 
zgłoszenia się do specjalisty w celu konsultacji przy wypisie ze szpitala, wypisanie pacjentowi skierowania do kardiologa przez lekarza prowadzącego, podanie Hydroxyzyny $25 \mathrm{mg}$ p.o. na zlecenie lekarza, zapewnienie atmosfery bezpieczeństwa.

Ocena działań: unormowanie wartości ciśnienia tętniczego krwi, problem wymaga dalszej kontynuacji działań.

\section{Zaburzenia oddawania stolca - zaparcia} spowodowane sytuacją stresową (hospitalizacja)

Cel opieki pielęgniarskiej: ułatwienie wypróżnienia.

Zastosowane interwencje pielęgniarskie: ocena rodzaju zaparć (zaparcia spowodowanie stresem), prowadzenie karty wypróżnień, prowadzenie bilansu płynów, zwiększenie podaży płynów, wprowadzenie do diety środków działających naturalnie przeczyszczająco (warzywa, owoce przyniesione przez rodzinę), zwiększenie aktywności fizycznej (wykonanie ćwiczeń izomerycznych mięśni brzucha podczas leżenia w łóżku w obecności fizjoterapeuty po uprzednim instruktażu pacjenta), podawanie środków wspomagających wypróżnienie na zlecenie lekarza: czopki glicerynowe (1 czopek/dobę, p.r.), podawano na zlecenie lekarza 2x15 ml Lactulose p.o.

Ocena działań: uzyskanie regularnego rytmu wypróżnień.

\section{Dyskomfort spowodowany unieruchomieniem chorego w łóżku}

Cel opieki pielęgniarskiej: poprawienie samopoczucia chorego.

Zastosowane interwencje pielęgniarskie: pomoc pacjentowi w zapewnieniu wygodnej pozycji ułożeniowej, pomoc pacjentowi przy toalecie ciała i zmianie bielizny osobistej, stosowanie profilaktyki przeciwodleżynowej (pomoc w zmianie pozycji, zastosowanie przewiewnego ubrania, zmiana bielizny pościelowej w razie potrzeby), zachęcenie pacjenta do czytania lub słuchania radia.

Ocena działań: zmniejszenie dyskomfortu z powodu unieruchomienia w łóżku.

\section{Brak apetytu i nudności spowodowane przyjmowanymi przez chorego lekami}

Cel opieki pielęgniarskiej: zwiększenie apetytu, brak nudności.

Zastosowane interwencje pielęgniarskie: podawanie doustnie płynów, estetyczna forma podawanych posiłków, wyeliminowanie z jadłospisu potraw o przykrym dla chorego zapachu, zachęcenie pacjenta do jedzenia, towarzyszenie choremu w trakcie posiłków, podawanie choremu kroplówki 1x500 ml 0,9\% NaCl i.v. na zlecenie lekarza, podanie 40 mg IPP i.v. na zlecenie lekarza.

Ocena działań: poprawa apetytu pacjenta.

\section{Zaburzenia snu - trudności w zasypianiu, krótki okres snu w ciągu nocy z powodu zmiany otoczenia, braku kontaktu z bliskimi, sytuacji stresowej}

Cel opieki pielęgniarskiej: sen dający choremu poczucie wypoczynku.

Zastosowane interwencje pielęgniarskie: wyeliminowanie czynników utrudniających zasypianie (wywietrzenie sali, zgaszenie światła o godz. 22, wyłączenie radia), założenie czystej bielizny pościelowej do spania, dobranie odpowiedniej bielizny osobistej chorego, przyniesionej przez rodzinę pacjenta, zachęcenie pacjenta do wyciszenia, eliminacja bólu u pacjenta poprzez farmakoterapię na zlecenie lekarza (1 g paracetamolu i.v., 2-4 mg morfiny s.c.), cicha i spokojna rozmowa z pacjentem przed snem, podawanie farmakoterapii na zlecenie lekarza w celu polepszenia zasypiania (hydroksyzyna $25 \mathrm{mg}$ p.o.).

Ocena działań: poprawa jakości snu chorego.

\section{Możliwość wystąpienia kolejnego zawału serca z powodu obecności czynników ryzyka}

Cel opieki pielęgniarskiej: wyeliminowanie nałogu palenia papierosów.

Zastosowane interwencje pielęgniarskie: uświadomienie pacjenta o związku palenia papierosów z występowaniem zawałów serca, poinformowanie o ujemnym wpływie palenia papierosów na ludzi dorosłych i dzieci jako biernych palaczy w środowisku, wskazanie pozytywnych aspektów płynących z rzucenia nałogu: zmniejszenie ryzyka wystąpienia zawału serca oraz innych chorób, poprawa ogólnej kondycji i wydolności, oszczędność, zmotywowanie pacjenta do rzucenia nałogu, zaproponowanie metody, która ułatwi zerwanie z nałogiem( rozmowa z rodziną, hobby, plastry antynikotynowe, terapia w grupie, aktywność fizyczna), opracowanie sposobów opanowania chęci zapalenia papierosa (żucie gumy zamiast zapalenia papierosa, odkładanie określonych sum pieniędzy w zamian za nie kupienie paczki papierosów), edukacja pacjenta przeprowadzona przez pielęgniarkę na oddziale.

Cel opieki pielęgniarskiej: prawidłowe odżywianie pacjenta, redukcja masy ciała.

Zastosowane interwencje pielęgniarskie: uświadomienie pacjenta o zależności między nieprawidłową masą ciała a ryzykiem wystąpienia zawału serca, poinformowanie pacjenta o korzyściach płynących z redukcji masy ciała, udostępnienie pacjentowi broszury z przykładowymi dietami, zachęcenie chorego do stopniowego zwiększenia aktywności fizycznej po wyjściu ze szpitala, na zlecenie lekarza przeprowadzenie konsultacji z rehabilitantem w celu ułożenia planu ćwiczeń dla pacjenta po wyjściu ze szpitala, wzmocnienie za- 
chowań prozdrowotnych, przekonanie pacjenta do spożywania większej ilości owoców i warzyw.

Cel opieki pielęgniarskiej: wyeliminowanie lub zminimalizowanie poziomu stresu.

Zastosowane interwencje pielęgniarskie: przekonanie pacjenta o negatywnym wpływie stresu na organizm, nauka chorego na temat rozpoznawania sytuacji stresowych (spóźnienie w pracy, problemy rodzinne, gubienie rzeczy) i sposobu ich eliminacji (liczenie od 1 do 10, rozmowa z najbliższymi, zapisywanie na kartkach rzeczy do zapamiętania, organizacja czasu w kalendarzu, wcześniejsze planowanie), nauczenie pacjenta technik relaksacyjnych (wizualizacja, głębokie oddychanie, plan aktywności fizycznej po wyjściu ze szpitala, napinanie i rozluźnianie mięśni), zaproponowanie zwiększenia uczucia tolerancji dla ludzi i zdarzeń (mówienie o problemach, rozwinięcie empatii), zachęcenie pacjenta do uregulowania rytmu snu, zachęcenie pacjenta do poświęcenia więcej czasu na swoje hobby.

Ocena działań: niemożliwe do oceny, problem wymaga dalszej kontynuacji działań.

\section{Dyskusja}

Opisany przypadek pokazał, iż opieka pielęgniarska stanowi ważny element leczenia pacjenta po zawale serca. Praca z pacjentem na Oddziale Intensywnej Opieki Kardiologicznej wymagała wnikliwej obserwacji chorego, parametrów życiowych, a także samopoczucia pacjenta. Istotną kwestią było zwrócenie uwagi na ryzyko wystąpienia groźnych dla życia pacjenta powikłań, jak: krwawienie z tętnicy poddanej nakłuciu lub wystąpienie ponownego zawału serca po angioplastyce wieńcowej. Powikłania sercowo-naczyniowe występują dosyć rzadko, u około 0,4-4,9\% chorych poddanych PCl. Najczęściej są to powikłania krwotoczne, które występują u 15-20\% pacjentów. Opieka pielęgniarska obejmuje kontrolę opatrunku uciskowego, prawidłowości jego umieszczenia i czasu założenia oraz sprawdzanie zabarwienia skóry, ciepłotę i obecność tętna na kończynie [12]. Dalsza opieka nad pacjentem opierała się na zmniejszeniu dolegliwości bólowych poprzez farmakoterapię, kontrolę efektu przeciwbólowego oraz obserwację sfery psychicznej chorego. W wyniku hospitalizacji pacjent był zaniepokojony swoim stanem zdrowia oraz zmianą otoczenia. Po interwencji personelu pielęgniarskiego chory miał możliwość rozmowy z lekarzem prowadzącym w celu dokładniejszego poznania swojego stanu zdrowia i zapoznania się z dalszym planem leczenia. Podczas wcześniejszej rozmowy z lekarzem pacjent nie zadał wszystkich pytań lekarzowi i nie przedstawił swoich obaw. Podano farmakoterapię na zlecenie lekarza przedstawioną w procesie pielęgnowania. W efekcie końcowym pacjent się uspokoił, przespał noc z przerwami oraz zmniejszyły się duszności chorego, a także zostały unormowane wartości ciśnienia tętniczego krwi. Obserwacja stanu psychicznego pacjenta miała duży wpływ na całokształt leczenia. Dolegliwości występujące u chorego były efektem zdenerwowania, niepokoju oraz braku dostatecznego kontaktu z personelem lekarskim. Kolejnym problemem pielęgnacyjnym były nawyki żywieniowe chorego, obecność nałogu, występowanie sytuacji stresowych w codziennym życiu. Interwencje pielęgniarskie ograniczały się do rozmów i przedstawiania programu ćwiczeń i rehabilitacji kardiochirurgicznej po opuszczeniu szpitala. Na Oddziale Intensywnej Opieki Kardiologicznej nie było możliwości przeprowadzenia odpowiedniej i rzetelnej edukacji pacjenta. W wyniku krótkiego okresu obserwacji nie było możliwości oceny pacjenta po wypisie, czy zastosował się on do przedstawionych zaleceń pielęgniarskich. Podsumowując, głównym celem leczenia i opieki pielęgniarskiej jest to, aby pacjent w jak największym stopniu powrócił do funkcjonowania w swoim środowisku domowym i zawodowym.

\section{Wnioski}

1. W wyniku zaplanowanego procesu opieki pielęgniarskiej pacjent w sposób bezpieczny i prawidłowy przebył okres hospitalizacji.

2. Zespół pielęgniarski właściwie rozpoznał problemy pielęgnacyjne chorego i zaplanował odpowiednie działania w celu uzupełnienia deficytów samoopieki dotyczących nie tylko podstawowych potrzeb biologiczno-fizycznych, ale także potrzeb psychospołecznych.

3. Pacjent przebywający na Oddziale Intensywnej Opieki Kardiologicznej wymaga intensywnej obserwacji i stałej kontroli parametrów życiowych w celu jak najwcześniejszego rozpoznania zaburzeń czynności życiowych, których bezpośrednim następstwem może być upośledzenie funkcji życiowych organizmu lub utrata życia.

\section{Piśmiennictwo}

1. WHO Facts sheet N8310, May 2018, https://www.who.int/ news-room/fact-sheets/detail/the-top-10-causes-ofdeath, dostęp: 30.06.2020.

2. Chlebus K, Gąsior M i wsp. Raport. Występowanie, leczenie i prewencja wtórna zawałów serca w Polsce. Ocena na podstawie Narodowej Bazy Danych Zawałów Serca (AMIPL 2099-2012). Warszawa, Zabrze, Gdańsk 2014. https:// www.pzh.gov.pl/raport-wystepowanie-leczenie-i-prewencja -wtornazawalow-serca-w-polsce/ dostęp: 30.06.2020.

3. Stępka A. Stany zagrożenia życia w chorobach układu krążenia, PZWL, Warszawa, 2019.

4. Piotrowska-Kownacka D. Ostry zespół wieńcowy i zawał mięśnia sercowego. [w:] Serce i duże naczynia. Diagnostyka obrazowa. Michałowska I, Hryniewiecki T, Furmanek MI, PZWL, Warszawa, 2014: 124-128. 
5. Thygesen K, Alpert JS, Allan SJ et al. Czwarta uniwersalna definicja zawału serca (2018), Kardiologia Polska, 2018, 76, 10: 1383-1415.

6. Warga M, Figiel $Ł$, Kasprzak JD. Markery niedokrwienia i martwicy mięśnia sercowego - stan obecny i perspektywy na przyszłość. Kardiologia po Dyplomie, 2010; 9(10): 55-73.

7. Boateng $S$, Sanborn T. Acute myocardial infarction. Dis Mon. 2013, 59(3): 83-96.

8. Gorol J, Polońskie L. Droga do nowoczesnego leczenia zawału serca - jakie były początki, gdzie jesteśmy obecnie?, Choroby Serca i Naczyń, 2017; 14(4): 194-200.

9. Kośmicki M. Choroba wieńcowa w praktyce lekarza rodzinnego, Termedia, Poznań, 2010.

10. Grupa Robocza Europejskiego Towarzystwa Kardiologicznego (ESC) do spraw postępowania w ostrym zawale serca z uniesieniem odcinka ST, Wytyczne ESC dotyczące postępowania w ostrym zawale serca z przetrwałym uniesieniem odcinka ST, Kardiologia Polska 2018, 76, 2: 229-313.

11. Mielech A, Rogula E. Główne powikłania w kardiologii inwazyjnej. Metody zapobiegania. [w:] Standardy opieki pielęgniarskiej w kardiologii inwazyjnej. Mroczkowska R, Serzysko B, Szkutnik M, PZWL, Warszawa, 2016: 58.
12. Lesiak A, Kołodziej W. Problemy związane z pielęgnacją pacjentów po interwencyjnych zabiegach kardiologicznych. Pielęgniarstwo Polskie 2016, 1(59): 37-42.

Artykuł przyjęty do redakcji: 24.03.2020.

Artykuł przyjęty do publikacji: 21.12.2020.

Źródło finansowania: Praca nie jest finansowana z żadnego źródła. Konflikt interesów: Autorzy deklarują brak konfliktu interesów.

\author{
Adres do korespondencji: \\ Kinga Duszak \\ W.H. Lindleya 4 \\ kod: 02-005 Warszawa \\ e-mail: kinga.duszak@wp.pl \\ Zakład Podstaw Pielęgniarstwa, Warszawski Uniwersytet Medyczny
}

